\title{
Hematological, serum biochemical and histopathological effects of selected herbs and combinations on Trypanosoma brucei infected West African dwarf sheep
}

\author{
OLUSEGUN A. OLATUNDE ${ }^{1, \vartheta}$, HENRY O. JEGEDE ${ }^{2, v,}$, SALIU A. AMEEN ${ }^{3}$ \\ ${ }^{1}$ Department of Theriogenology and Production, Faculty of Veterinary Medicine, University of Ilorin. Ilorin, Nigeria. \\ Tel./fax.: +234-803-3953880, vemail: tundeola@unilorin.edu.ng \\ ${ }^{2}$ Veterinary Teaching Hospital, University of Ilorin. Ilorin, Nigeria."vemail: drlanrejeg@gmail.com \\ ${ }^{3}$ Department of Veterinary Medicine, Faculty of Veterinary Medicine. University of Ilorin, Ilorin, Nigeria
}

Manuscript received: 19 July 2020. Revision accepted: 4 January 2021.

\begin{abstract}
Olatunde OA, Jegede HO, Ameen SA. 2021. Hematological, serum biochemical and histopathological effects of selected herbs and combinations on Trypanosoma brucei infected West African dwarf sheep. Asian J Nat Prod Biochem 19: 10-16. The present work was carried out to study the hematological, serum biochemical and histopathological effects of selected herbal diets on trypanosomeinfected West African dwarf sheep. Five incorporated herbal diets were tested where A is the control diet, B is Citrus aurantifolia, C is Ocimum gratissimum, D is Vernonia amygdalina + Citrus aurantifolia, and E is Ocimum gratissimum + Vernonia amygdalina. Sheep on Diets E, A, C, B, and D consumed $856.4 \mathrm{~g} / \mathrm{d}, 830 \mathrm{~g} / \mathrm{d}, 750.0 \mathrm{~g} / \mathrm{d} .734 .0 \mathrm{~g} / \mathrm{d}$ and $687.0 \mathrm{~g} / \mathrm{d}$, respectively, showing more acceptability to diet E. Additionally, sheep on Diet E was highest in RBC, WBC, Hb, lymphocyte, PCV, and basophils. The least hematological indices were recorded for the animals on the Control diet (A), showing that all herbal diets improved blood indices of the infected sheep. The ALP concentration was significantly different (17.000i.u/l) in Diet B compared to other Diets. At the same time, the least ALP was noted for sheep on Diets A and B. Herbs and combinations used in this study significantly improved both hematological and pathological lesions seen in experimental trypanosomosis caused by Trypanosoma brucei infection in sheep. The best results were obtained from Diet E combinations.
\end{abstract}

Keywords: Hematology, herbal diets, pathology, production, trypanosomosis

\section{INTRODUCTION}

Herbal phytochemical constituents in diet or administered to animals by any routes undergo biotransformation by the principal metabolic organs like the liver, kidney, and lungs (Aliu 2007). The detoxification of any substance in the animal body involves several enzymes, cytochrome oxidases, and microsomal enzymes (Aliu 2007). The metabolism of xenobiotics or any foreign substance in the animal's body could affect the hepatic enzymes principally and various biochemical parameters: bilirubinbin and conjugated bilirubin concentration, electrolytes, creatinine, urea, protein, and cholesterol. Yakubu et al. (2005) evaluated the effects of plants by assessing their biochemical parameters, which give insight into the effect of phytochemical substances on biochemical parameters to note the detrimental effect or beneficial effects of the substances. Some factors could influence the positive or negative effect of plants on animal health amongst which include species of animal, age, the concentration of the substance, lethality of substance, the health status of the animal, sex, nutritional status of the animal, geographical zone from which plant is obtained and route of administration (Awoyomi et al. 2013).

Trypanosomosis is a protozoan disease affecting various animals, including sheep, and causing severe hematologic problems, the most prominent being anemia
(Joshua et al., 1996), where the severity of the disease and tolerance of the parasite is affected by other factors, such especially the stress (Itard 1989). Most of the herbs thereby selected in this study have been known for their antioxidant effects.

This study, therefore, aimed to evaluate the safety and efficacy of some of these herbs, where hematological, biochemical, and histopathological parameters of sheep infected with Trypanosoma brucei and treated with selected spices and herbs.

\section{MATERIALS AND METHODS}

\section{Study area}

The study was conducted at the Teaching and Research Farm of the Faculty of Agriculture, University of Ilorin. The study lasted for three (3) weeks.

\section{Procedures \\ Experimental animals and management}

Fifteen (15) West African dwarf (WAD) adult sheep (2-4 years) used for this study were randomly assigned to five (5) treatments consisting of three (3) animals per treatment group, in a Completely Randomized Design. Ten (10) $\mathrm{ml}$ of blood samples were collected using an 18-gauge needle via the jugular vein of the sheep, and $5 \mathrm{ml}$ each was 
distributed into bottles coated with ethylene diamine tetraacetate (EDTA) and plain bottles for hematology and serology, respectively.

\section{Inoculation Procedure}

The strain of Trypanosoma brucei was obtained from the Nigerian Institute of Trypanosomiasis Research (NITR), Vom, Jos. The parasites were inoculated into two albino rats. The rats were later bled during the first wave of parasitemia into an EDTA container (Ethylene diamine tetraacetic acid). The phase-contrast buffy coat technique (Biobaku et al. 2008) was used to detect and quantify trypanosomes in the blood samples using Standard methods (Murray et al. 1983). WAD sheep previously screened for trypanosome were inoculated intramuscularly with $3 \mathrm{mls}$ of Phosphate Buffered Saline containing 1.5× $10^{6}$ Trypanosoma brucei. The trypanosome species was confirmed in the infected WAD sheep following a laboratory blood test (Murray et al. 1983) on the 6th day post-infection.

\section{Preparation of plant spices}

Some plant samples (leaves from Citrus aurantifolia with voucher no: UILH/003/983; Ocimum gratissimum with voucher no: UILH/002/1984; Vernonia amygdalina with voucher no: UILH/001/1023) were collected within the University of Ilorin, Nigeria. The samples were identified at the Department of Plant Science, University of Ilorin, Nigeria. The collected samples were washed in a running tap to remove soil and dust particles. It was later air-dried on the laboratory bench for five days. The dried samples were milled with pestle and mortar into a powdery form. The powdered samples were stored in a dry, clean container with a lid. These were mixed with prepared diets at a 5\% inclusion rate, as shown in Table 1. In combinations, e.g., (VA+CA), herbs were mixed in equal ratios i.e., 1:1. The diets were fed to the sheep for three weeks based on the group they belonged to.

\section{Experimental Diets and Feeding}

Throughout the experiment, animals were fed experimental diets (Table 1) based on 3\% of their weight twice per day, and water was given to them ad libitum. They were on these diets until the experiment was terminated at the end of three weeks.

\section{Hematological analysis}

The blood samples were taken at 1 week and 2 weeks post-treatment and analyzed for Packed Cell Volume (PCV), Hemoglobin concentration ( $\mathrm{Hb})$, Red Blood Cell (RBC) counts, and differential leucocytes by standard hematological techniques (Jain 1986).

\section{Serum biochemical analysis:}

Five $(5 \mathrm{~mL})$ blood sample was collected into plain (anticoagulant free) plastic tube and allowed to clot at room temperature within 3 hours of collection. The serum samples were separated and stored at $-20^{\circ} \mathrm{C}$ for biochemical analysis. The serum concentration of total protein, albumin, aspartate transaminase (AST), alanine transaminase (ALT), and alkaline phosphatase (ALP) were determined by the colorimetric method as described by Reitman and Frankel (1975). Blood glucose was determined by the standard method described by Kaneko and Howard (1989).

\section{Histopathological examination:}

Post-study, one animal per group (A-E) was sacrificed in order to obtain fresh samples for examination. According to Drury and Wallington, samples of the spleen, kidney, and liver were collected in formalinized saline solution for histopathology and were processed and routinely stained with hematoxylin and eosin (H\&E) according to Drury and Wallington (1967). The lesions were examined under a microscope (x100).

\section{Data analysis}

Data resulting from our study were expressed in Means and standard error of the mean (SEM). Monitored physiological variables were analyzed using analyses of variance (ANOVA) for repeated measures, and $\mathrm{P}<0.05$ was accepted as significant.

Table 1. Composition of the experimental diets for West African Dwarf (WAD) Sheep

\begin{tabular}{|c|c|c|c|c|c|}
\hline Ingredient \% & $\begin{array}{l}\text { A } \\
\text { (Control) }\end{array}$ & $\begin{array}{l}\text { B } \\
\text { (CA) }\end{array}$ & $\begin{array}{l}\mathrm{C} \\
(\mathrm{OG})\end{array}$ & $\begin{array}{l}\text { D } \\
(\mathrm{VA}+\mathrm{CA})\end{array}$ & $\begin{array}{l}\mathbf{E} \\
(\mathrm{OG}+\mathrm{VA})\end{array}$ \\
\hline Cassava waste & 60.00 & 55.00 & 55.00 & 55.00 & 55.00 \\
\hline Plant extract & - & 5.00 & 5.00 & 5.00 & 5.00 \\
\hline Soyabean meal & 16.00 & 16.00 & 16.00 & 16.00 & 16.00 \\
\hline Rice husk & 22.00 & 22.00 & 22.00 & 22.00 & 22.00 \\
\hline \multicolumn{6}{|c|}{ Vitamin-Minerals } \\
\hline Premix & 1.00 & 1.00 & 1.00 & 1.00 & 1.00 \\
\hline Salt & 1.00 & 1.00 & 1.00 & 1.00 & 1.00 \\
\hline Total & 100.00 & 100.00 & 100.00 & 100.00 & 100.00 \\
\hline
\end{tabular}




\section{RESULTS AND DISCUSSION}

\section{Hematological observations}

Sheep on Diets E, A, C, B, and D consumed an average of $856.4 \mathrm{~g} / \mathrm{d}, 830 \mathrm{~g} / \mathrm{d}, 750.0 \mathrm{~g} / \mathrm{d} .734 .0 \mathrm{~g} / \mathrm{d}$ and $687.0 \mathrm{~g} / \mathrm{d}$, respectively. It was observed from Tables 2 and 3 that RBC and PCV were significantly different $(\mathrm{p}<0.05)$ across the various dietary treatments, and likewise are \% eosinophils and $\%$ monocytes concentration $(\mathrm{p}<0.05)$. WAD sheep in the control group and Diet B (CA) had a significantly $(\mathrm{p}<0.05)$ lower WBC concentration $\left(4.56-4.9 \times 10^{9} / \mathrm{L}\right)$, respectively, when compared to other dietary treatments. However, sheep on Diet D (VA+CA) had numerically higher $\left(7.23 \times 10^{9} / \mathrm{L}\right) \quad \mathrm{WBC}$ levels than other dietary treatments. Hemoglobin concentration difference was not significant $(p>0.05)$ across treatments though it was numerically higher in Diet $\mathrm{E}(\mathrm{OG}+\mathrm{VA})$. WAD sheep placed on Diet D (VA+CA) and Diet E (OG+VA) showed higher lymphocytes of $66 \%$ but lower neutrophils of 28$29 \%$. PCV was significantly lower $(\mathrm{p}<0.05)$ in Diet $\mathrm{E}$ (OG+VA) (27.66\%) compared with control A $(9.0 \%)$; however, Diet E (OG+VA) and Diet D (VA+CA) were similar. $\mathrm{WBC}$ followed the trend, with control Diet A lowest $\left(4.1 \times 10^{9} / \mathrm{L}\right.$, and Diet $\mathrm{E}(\mathrm{OG}+\mathrm{VA})$ being the highest $\left(8.4 \times 10^{9} / \mathrm{L}\right)$. Animals on Diet D (VA+CA) also showed higher $\left(6.5 \times 10^{9} / \mathrm{L}\right) \mathrm{WBC}$ count than those on Diet $\mathrm{B}(\mathrm{CA})$ and Diet $\mathrm{C}(\mathrm{OG})$. The same trend was observed in $\mathrm{RBC}$ and $\mathrm{Hb}$ count, as Diet $\mathrm{E}(\mathrm{OG}+\mathrm{VA})$ had higher counts $\left(2.4 \times 10^{12} / \mathrm{L}\right)$ and $(6.4 \mathrm{~g} / \mathrm{dl})$, respectively, when compared across other dietary treatments. Lymphocytes (\%) were significantly higher $(\mathrm{p}<0.05)$ in the herbal mixtures $(66.00$ $67.00 \%$ ) than in the single herb diet, but in terms of $\%$ neutrophils, in herbal mixtures was lower $(22-26 \%)$ than in other (33-39\%), with diet B (CA) having the highest (44\%).

\section{Serum biochemical observations}

From Table 4, ALP was significantly higher $(\mathrm{p}<0.05)$ in Diet B (CA) (17.0 IU/L) when compared with the control (12.667 IU/L) and Diet D (VA+CA) (12.0 IU/L), however, observable significant $(\mathrm{p}>0.05)$ differences were recorded for Diet C (OG), Diet E (OG+VA) and the control. AST concentration showed that diet mixtures, Diet $\mathrm{D}(\mathrm{VA}+\mathrm{CA})$ and Diet $\mathrm{E}(\mathrm{OG}+\mathrm{VA})$, were significantly higher $(\mathrm{p}<0.05)$ at 44.67 IU/L and 46.00 IU/L, respectively, compared to other dietary treatments. Glucose level was lowest $(\mathrm{p}>0.05)$ in Diet $\mathrm{E}(\mathrm{OG}+\mathrm{VA})$ treatment $(2.96 \mathrm{mmol} / \mathrm{l})$ but highest in control A (4.23 mmol/l). This trend continued in the ALT as the control group was significantly lower (17.00 IU/L, $\mathrm{p}<0.05)$ than those observed in other treatments. Serum protein also followed the trend, with the control at 23.9 $\mathrm{mmol} / \mathrm{l}(\mathrm{p}<0.05)$. However, Diet B $(\mathrm{CA})$ had the highest $(\mathrm{p}<0.05)$ serum protein level $(32.1 \mathrm{mmol} / \mathrm{l})$.

Tables 4 and 5 show that AST and Albumin levels were significantly lower $(\mathrm{P}<0.05)$ in Diet $\mathrm{E}(\mathrm{OG}+\mathrm{VA})(13.0$ IU/L) and (13.9 mmol/L), respectively, compared across dietary treatments, AST was higher (44.0 IU/L, p<0.05) in Diet D (VA+CA) than Diet B (CA) (37.0 IU/L), B(OG) (33.0 IU/L) and the control A (33.0 IU/L). ALT in Diet E $(\mathrm{OG}+\mathrm{VA})$ was significantly higher $(\mathrm{P}<0.05)$ at $50.00 \mathrm{IU} / \mathrm{L}$ than that observed in other treatments, diet $\mathrm{B}$ (CA) treatment also was higher $(29.0 \mathrm{IU} / \mathrm{L}, \mathrm{p}<0.05)$ than the control A (16.0 IU/L) and to both Diet C (OG) and Diet D (VA+CA) which were comparable in ALT concentration (24-25 IU/L, p<0.05). In terms of serum glucose level, no significant difference $(\mathrm{P}>0.05)$ was observed across all dietary treatments.

\section{Histopathology observations}

The spleen demonstrated various degrees of severity of hyperplasia of the lymphoid follicles. The cortical and medullary regions of the lymph nodes showed congestion of the sinuses, proliferation of mononuclear cells, erythrophagocytosis, and hemosiderosis. The kidneys similarly demonstrated various degrees of congestion, perivascular and interstitial mononuclear cell infiltration, thickening of glomerular capsules, desquamation of tubular cells, and protein casts in the tubules.

Table 2. Hematological Indices of WAD Sheep one-week post-infection placed on various experimental (herbal-based) diets

\begin{tabular}{|c|c|c|c|c|c|}
\hline Parameters & $\begin{array}{l}\text { A } \\
\text { Control }\end{array}$ & $\begin{array}{l}\text { B } \\
\text { CA }\end{array}$ & $\begin{array}{l}\mathrm{C} \\
\text { OG }\end{array}$ & $\begin{array}{l}\mathrm{D} \\
\mathrm{VA}+\mathrm{CA}\end{array}$ & $\begin{array}{l}\mathbf{E} \\
\mathrm{OG}+\mathrm{VA}\end{array}$ \\
\hline Red Blood Cell (x 10²/L) & $1.33 \pm 0.15$ & $1.30 \pm 0.11$ & $1.20 \pm 0.20^{c}$ & $1.57 \pm 0.65$ & $1.67 \pm 0.39$ \\
\hline White Blood cell (x 109/L) & $4.57 \pm 0.09^{\mathrm{a}}$ & $4.90 \pm 0.43^{\mathrm{a}}$ & $6.50 \pm 0.29^{b}$ & $7.23 \pm 1.23^{\mathrm{b}}$ & $6.80 \pm 0.99^{\mathrm{b}}$ \\
\hline Haemoglobin $(\mathrm{g} / \mathrm{dl})$ & $3.60 \pm 0.12^{\mathrm{b}}$ & $4.10 \pm 0.22^{\mathrm{ab}}$ & $4.30 \pm 0.13^{\mathrm{ab}}$ & $5.00 \pm 0.33^{\mathrm{ab}}$ & $5.20 \pm 0.44^{\mathrm{a}}$ \\
\hline Lymphocytes (\%) & $54.000 \pm 0.45^{\mathrm{a}}$ & $58.00 \pm 1.06^{\mathrm{b}}$ & $55.00 \pm 0.96^{\mathrm{a}}$ & $66.00 \pm 0.66^{c}$ & $66.00 \pm 0.62^{c}$ \\
\hline Neutrophils (\%) & $39.00 \pm 1.11^{\mathrm{a}}$ & $39.00 \pm 1.77^{a}$ & $32.00 \pm 1.22^{\mathrm{b}}$ & $28.00 \pm 1.07^{\mathrm{b}}$ & $29.00 \pm 1.09^{b}$ \\
\hline Eosinophils (\%) & $3.00 \pm 0.32$ & $3.00 \pm 0.28$ & $5.00 \pm 0.45$ & $5.00 \pm 0.42$ & $1.33 \pm 0.25$ \\
\hline Packed Cell Volume (\%) & $15.00 \pm 0.09$ & $15.00 \pm 0.13$ & $13.00 \pm 0.20$ & $18.00 \pm 0.23$ & $20.00 \pm 1.92$ \\
\hline Basophils (\%) & $0.67 \pm 0.02^{\mathrm{ab}}$ & $0.67 \pm 0.03^{\mathrm{ab}}$ & $0.01 \pm 0.01^{\mathrm{a}}$ & $0.67 \pm 0.08^{\mathrm{ab}}$ & $3.00 \pm 0.12^{\mathrm{a}}$ \\
\hline Monocytes (\%) & $0.67 \pm 0.02$ & $0.67 \pm 0.04$ & $0.67 \pm 0.02$ & $0.01 \pm 0.00$ & $1.00 \pm 0.04$ \\
\hline
\end{tabular}

Note: Values are Mean \pm S.E.M. Means with different superscripts along the same row are significantly different $(\mathrm{P}<0.05)$, CA: Citrus aurantifolia; OG: Occimum gratissimum; VA+CA: Vernonia amygdalina + Citrus aurantifolia; OG+VA: Occimum gratissimum + Vernonia amygdalina 
Table 3. Hematological Indices of WAD Sheep two weeks post-infection placed on various experimental (herbal-based) Diets

\begin{tabular}{llllll}
\hline \multirow{2}{*}{ Parameters } & $\begin{array}{l}\text { A } \\
\text { Control }\end{array}$ & $\begin{array}{l}\text { B } \\
\text { CA }\end{array}$ & $\begin{array}{l}\text { C } \\
\text { OG }\end{array}$ & $\begin{array}{l}\text { D } \\
\text { VA+CA }\end{array}$ & $\begin{array}{l}\text { E } \\
\text { OG+VA }\end{array}$ \\
\hline Red Blood Cell (x 1012/L) & $1.00 \pm 0.09^{\mathrm{a}}$ & $1.30 \pm 0.13^{\mathrm{b}}$ & $1.50 \pm 0.15^{\mathrm{c}}$ & $1.60 \pm 0.22^{\mathrm{c}}$ & $2.40 \pm 0.32^{\mathrm{d}}$ \\
White Blood Cell (x 10/L) & $4.10 \pm 0.48^{\mathrm{a}}$ & $5.20 \pm 0.56^{\mathrm{b}}$ & $5.50 \pm 0.65^{\mathrm{c}}$ & $6.50 \pm 0.88^{\mathrm{d}}$ & $8.40 \pm 0.89^{\mathrm{e}}$ \\
Haemoglobin (g/dl) & $2.90 \pm 0.09^{\mathrm{a}}$ & $4.00 \pm 0.34^{\mathrm{c}}$ & $3.20 \pm 0.31^{\mathrm{ab}}$ & $4.60 \pm 0.39^{\mathrm{d}}$ & $6.40 \pm 0.26^{\mathrm{e}}$ \\
Lymphocytes (\%) & $53.00 \pm 0.61^{\mathrm{a}}$ & $55.00 \pm 0.63^{\mathrm{b}}$ & $60.00 \pm 0.67^{\mathrm{c}}$ & $67.00 \pm 0.76^{\mathrm{d}}$ & $67.00 \pm 0.60^{\mathrm{d}}$ \\
Neutrophils (\%) & $39.00 \pm 0.45^{\mathrm{d}}$ & $44.00 \pm 0.46^{\mathrm{e}}$ & $33.00 \pm 0.40^{\mathrm{c}}$ & $22.00 \pm 0.74^{\mathrm{a}}$ & $26.00 \pm 0.62^{\mathrm{b}}$ \\
Eosinophils(\%) & $4.00 \pm 0.12^{\mathrm{c}}$ & $1.00 \pm 0.03^{\mathrm{a}}$ & $5.00 \pm 0.11^{\mathrm{d}}$ & $10.00 \pm 1.12^{\mathrm{e}}$ & $2.00 \pm 0.44^{\mathrm{b}}$ \\
Packed Cell Volume (\%) & $9.00 \pm 0.45^{\mathrm{a}}$ & $14.00 \pm 0.34^{\mathrm{c}}$ & $13.00 \pm 0.76^{\mathrm{b}}$ & $17.00 \pm 0.88^{\mathrm{d}}$ & $27.67 \pm 0.82^{\mathrm{e}}$ \\
Basophils (\%) & $1.33 \pm 0.05^{\mathrm{b}}$ & $0.00 \pm 0.00^{\mathrm{a}}$ & $0.01 \pm 0.01^{\mathrm{a}}$ & $0.01 \pm 0.01^{\mathrm{a}}$ & $3.00 \pm 0.10^{\mathrm{c}}$ \\
Monocytes (\%) & $3.00 \pm 0.14^{\mathrm{e}}$ & $0.01 \pm 0.01^{\mathrm{a}}$ & $1.33 \pm 0.11^{\mathrm{bc}}$ & $1.00 \pm 0.04^{\mathrm{ab}}$ & $2.33 \pm 0.46^{\mathrm{d}}$ \\
\hline
\end{tabular}

Note: Values are Mean \pm S.E.M. Mean with different superscripts along the same row are significantly different $(\mathrm{P}<0.05)$, CA: Citrus aurantifolia; OG: Ocimum gratissimum; VA+CA: Vernonia amygdalina + Citrus aurantifolia; OG+VA: Ocimum gratissimum + Vernonia amygdalina

Table 4. Serum Biochemical Indices of WAD Sheep one-week post-infection placed on various experimental (herbal-based) diets

\begin{tabular}{llllll}
\hline \multirow{2}{*}{ Serum parameters } & A & B & C & D & E \\
& Control & CA & OG & VA+CA & $\begin{array}{l}\text { OG+ VA } \\
\text { OG (IU/L) }\end{array}$ \\
\hline ALP (IU/L) & $12.67 \pm 0.89^{\mathrm{ab}}$ & $17.00 \pm 1.92^{\mathrm{e}}$ & $16.00 \pm 1.96^{\mathrm{d}}$ & $12.00 \pm 2.69^{\mathrm{a}}$ & $13.67 \pm 0.88^{\mathrm{c}}$ \\
AST (IU/L) & $29.00 \pm 1.34^{\mathrm{a}}$ & $35.00 \pm 1.03^{\mathrm{c}}$ & $31.00 \pm 1.92^{\mathrm{b}}$ & $44.67 \pm 1.62^{\mathrm{d}}$ & $46.00 \pm 0.98^{\mathrm{e}}$ \\
GLUC (mmol/L) & $4.23 \pm 0.45^{\mathrm{e}}$ & $3.23 \pm 0.54^{\mathrm{b}}$ & $4.00 \pm 0.21^{\mathrm{d}}$ & $3.80 \pm 0.27^{\mathrm{c}}$ & $2.97 \pm 0.31^{\mathrm{a}}$ \\
ALT (IU/L) & $17.00 \pm 0.93^{\mathrm{a}}$ & $27.00 \pm 1.12^{\mathrm{e}}$ & $24.00 \pm 1.02^{\mathrm{b}}$ & $26.67 \pm 1.00^{\mathrm{d}}$ & $24.67 \pm 1.40^{\mathrm{c}}$ \\
Total Protein (mmol/L) & $23.90 \pm 0.62^{\mathrm{a}}$ & $32.10 \pm 0.70^{\mathrm{d}}$ & $25.43 \pm 0.69^{\mathrm{ab}}$ & $27.40 \pm 0.81^{\mathrm{bc}}$ & $30.00 \pm 0.97^{\mathrm{cd}}$ \\
Albumin (mmol/L) & $15.53 \pm 0.09^{\mathrm{c}}$ & $15.80 \pm 0.12^{\mathrm{d}}$ & $16.00 \pm 0.23^{\mathrm{e}}$ & $14.80 \pm 0.11^{\mathrm{a}}$ & $14.85 \pm 0.11^{\mathrm{ab}}$ \\
\hline
\end{tabular}

Note: Values are Mean \pm S.E.M. Means with different superscripts along the same row are significantly different (P<0.05), CA: Citrus aurantifolia; OG: Occimum gratissimum; VA+CA: Vernonia amygdalina + Citrus aurantifolia; OG+VA: Occimum gratissimum + Vernonia amygdalina, ALP: Alanine Phosphatase; AST: Aspartate aminotransferase transaminase; GLUC: Glucose; ALT: Alanine aminotransferase transaminase; Albu: Albumin.

In the study, the livers showed various degrees of vascular congestion, perivascular cuffing of mononuclear cells, hepatocellular degeneration, and erythrophagocytosis in group A while in groups (B-E), the lesions are milder. The spleen of trypanosome-infected animals in group A showed depopulated red pulp, the proliferation of macrophages characterized by erythrophagocytosis and haemosiderosis, as well as the proliferation of plasma cells. The lesions are milder in various groups treated with spices (B-E).

\section{Discussion}

Studies have shown a progressive decrease in PCV and RBC in sheep (Mackenzie et al. 1978; Okaiyeto et al. 2010) infected with trypanosomes. The normal PCV values for healthy sheep ranged from $27-45 \%$ (Pugh 2002); therefore, the increase in PCV of sheep from 20-27\% that was observed in Diet E (OG+VA) two weeks post-infection with $T$. brucei suggested effective trypanosomatid or trypanotolerant effect of certain herbs or just an increased repair mechanism resulting from the combined antioxidant effects of the plants. Marcotty et al. (2008) observed that mean PCV was a good indicator of the health status of animals in an endemic area. In this study, the upturn of $\mathrm{PCV}$ in group $\mathrm{E}$ is indicative of a recovery from the effects of the trypanosome infection. The level of anemia or the PCV usually gives a reliable insight into an infected animal's disease status and productive performance (Van den Bossche et al. 2001). With improved PCV in blood, enhanced nutrient transport is achieved, leading to efficient feed utilization and absorption, implying better body weight gain (Katunguka-Rwakishaya et al. 1998). Furthermore, the increase observed in the level of RBC and hemoglobin in Diet E (OG+ VA) between weeks one and 2 and the significant difference between the control and other diets duly buttresses the point that it proffers a better immunosuppressive potential against the trypanosome. It has been shown that the onset of anemia, characteristics of trypanosomiasis, occurs within a few days of inoculation. There are conspicuous indications that the onset of anemia in African trypanosomiasis may be markedly related to interference with the erythrocyte membrane caused directly by parasite attack on red blood cells (Orhue and Nwanze 2009; Biobaku et al. 2009). It has also been suggested that products secreted by the protozoan play a significant role in the disruption of the red cell membrane (Li et al. 2007; Biobaku et al. 2008; Awoyomi et al. 2013), e.g., reduction in red cell membrane sialoglycoprotein secondary to increased activity of plasma sialidases promoting the rapid destruction of red blood cells (Awoyomi et al. 2013). The observable faster recovery rate from anemia (i.e., increased RBC count) in Diet E (OG+ VA) showed that Diet E (OG+ VA) herbal treatment exhibited remarkable potency in protecting against the hematological problems accompanying $T$. bruce $i$ infection in sheep. On the one hand, it is possible that the herbs 
may possess the ability to maintain the structural and functional capacity of the erythrocytic membrane or erythropoietic tissues to varying levels in the face of a hemiparasitic infection, having anti-anemic properties (Ikpeazu et al. 2019). On the other, since T. brucei infection is associated with a considerable generation of free radicals (Igbokwe et al. 1994), the antioxidant activity inherent in these plants is used (Awah 2010; Ho et al. 2012) may contribute significantly to the overall effects observed in this study. Furthermore, the herbs may possess a measure of trypanocidal activity or immuno-stimulating properties that helps put the parasite at bay and thus also control the injurious effects of uncontrolled hemiparasite proliferation.

It is worthy of note that compared with the control, the normal WBC level of sheep, which is $4-12 \times 10^{9} / \mathrm{L}$ in the herbal mixtures' treatment, increased in response to the pathogenic invasion. Diet $\mathrm{E}(\mathrm{OG}+\mathrm{VA})$ recorded a higher WBC count and subsequently a higher \% lymphocyte count. This implies that the immune system is fighting back to suggest host tolerance to the pathogen. In two separate studies, Oduye and Okunaiya (1971) and Murray et al. (1978) showed that the trypanotolerant N'dama cattle breed significantly had a higher level of WBC, particularly eosinophils, after being exposed to the pathogen. The increased WBC observed in all herbal based diets (B, C, D, and $\mathrm{E}$ ) compared with control diet A could also be inferred that several phytochemicals interact in the herbal mix, especially flavonoids, to assist the body in resisting diseases (Hoet et al. 2007), by boosting their capacity to ward off infection (WBC activation) even in the presence of an overwhelming infection like T. brucei in this study. Medicinal plants commonly have several chemicals working together catalytically and synergistically to produce a combined effect that surpasses the total activity of the individual constituents. The combined action of these substances increases the activity of the main medicinal constituent by speeding up or slowing down its assimilation into the body (Mahomoodally et al., 2005; 2010). Secondary substances from plant origins might increase the stability of the active compound(s) or phytochemicals, minimize the rate of undesired side effects, and have an additive, potentiating, or antagonistic effect (Mahomoodally et al. 2005; 2010). Alternatively, differences in levels of cellular response and degree of immunosuppression might just reflect differences in levels of parasitemia observed in the infected animals (Morrison et al. 1987).

Hypoalbuminemia observed on animals on diets B, C, $\mathrm{D}$, and $\mathrm{E}$ are characteristic of an infection mode in an animal body system. This is evident in the uptake of albumin-bound fatty acids, lipoprotein, and hemomodulation (Mbaya et al., 2012). Elevation in globulin due to enhanced antibody secretion in response to infection would undoubtedly have contributed immensely to the observed hyperproteinemia.

The increase in serum total protein (Table 5) may have been due to the increased release of tissue-specific enzymes and other intracellular proteins secondary to parasiteinduced cell membrane disruption. Although within the normal range, the increased transaminase was observed in all herbal treated diets (B, C, D, and E). This result supported an earlier study that reported a marked elevation in the serum levels of alkaline phosphatase (ALP), aspartate aminotransaminase (AST), and alanine amino transaminase (ALT) in Trypanosoma brucei infected rabbits (Dina et al. 2002). As observed in the various treatments (Tables 4 and 5), elevations in these enzymes are usually secondary to tissue damage. This is because such damage results in the leakage of these enzymes from their intracellular stores into plasma. The significant increase in the transaminases commonly accompanies such liver diseases as toxic hepatitis, acute liver necrosis, or hepatic cirrhosis. Increased AST is often observed in hemolytic anemia, myocardial infarction, and cholestatic diseases of the liver (Felix and Mello 2005). OG is a known hypoglycemic agent (Aguiyi et al. 2000), which agrees with our findings in this study. However, this hypoglycemic effect is shown to be amplified in combination with VA in diet E. Many hemoprotozoans, such as trypanosomes, depend on the host glucose for aerobic glycolysis (Riou and Bernard 1980). This will prevent glucose utilization by the parasites.

Table 5. Serum biochemical indices of WAD Sheep two weeks post-infection placed on various experimental (herbal-based) Diets

\begin{tabular}{llllll}
\hline Serum parameters & $\begin{array}{l}\text { A } \\
\text { (Control) }\end{array}$ & $\begin{array}{l}\text { B } \\
\text { (CA) }\end{array}$ & $\begin{array}{l}\text { C } \\
\text { (OG) }\end{array}$ & $\begin{array}{l}\text { D } \\
\text { (VA+CA) }\end{array}$ & $\begin{array}{l}\text { E } \\
(\text { OG+ VA) }\end{array}$ \\
\hline AST (IU/L) & $30.00 \pm 1.34^{\mathrm{b}}$ & $37.00 \pm 1.23^{\mathrm{d}}$ & $33.00 \pm 0.34^{\mathrm{c}}$ & $44.00 \pm 2.34^{\mathrm{e}}$ & $13.00 \pm 0.76^{\mathrm{a}}$ \\
ALT (IU/L) & $16.00 \pm 1.58^{\mathrm{a}}$ & $29.00 \pm 2.39^{\mathrm{d}}$ & $24.00 \pm 1.34^{\mathrm{b}}$ & $25.00 \pm 1.40^{\mathrm{c}}$ & $50.00 \pm 1.95^{\mathrm{e}}$ \\
GLUC (mmol/L) & $4.10 \pm 0.92^{\mathrm{e}}$ & $3.30 \pm 0.86^{\mathrm{b}}$ & $4.00 \pm 0.96^{\mathrm{d}}$ & $3.90 \pm 0.71^{\mathrm{c}}$ & $3.20 \pm 0.63^{\mathrm{a}}$ \\
ALP (IU/L) & $12.00 \pm 1.34^{\mathrm{b}}$ & $17.00 \pm 1.14^{\mathrm{c}}$ & $15.00 \pm 1.12^{\mathrm{d}}$ & $11.00 \pm 0.88^{\mathrm{a}}$ & $28.00 \pm 1.46^{\mathrm{e}}$ \\
Total Protein (mmol/L) & $20.70 \pm 0.23^{\mathrm{a}}$ & $30.30 \pm 0.49^{\mathrm{c}}$ & $29.60 \pm 0.45^{\mathrm{b}}$ & $32.40 \pm 0.57^{\mathrm{e}}$ & $32.00 \pm 0.56^{\mathrm{d}}$ \\
Albumin (mmol/L) & $14.60 \pm 0.23^{\mathrm{c}}$ & $15.50 \pm 0.18^{\mathrm{d}}$ & $13.90 \pm 0.04^{\mathrm{a}}$ & $14.20 \pm 0.05^{\mathrm{b}}$ & $13.90 \pm 0.19^{\mathrm{a}}$ \\
\hline
\end{tabular}

Note: Values are Mean \pm S.E.M. Means with different superscripts along the same row are significantly different (p<0.05), CA: Citrus aurantifolia; OG: Ocimum gratissimum; VA+CA: Vernonia amygdalina + Citrus aurantifolia; OG+VA: Ocimum gratissimum + Vernonia amygdalina, ALP: Alanine Phosphatase; AST: Aspartate aminotransferase transaminase; GLUC: Glucose; ALT: Alanine aminotransferase transaminase; Albu: Albumin. 
In this study, the presence of increased hemosiderosis indicates the major role the spleen plays in the destruction of red blood cells during trypanosomiasis in the control group A. This conforms to observations of Taylor and Authie (2004). The presence of grander lesions, such as erythrophagocytosis in $T$. brucei illnesses, especially those in the acute phase of infection, could have led to the rapid development of anemia regardless of the increased erythroid hyperplasia usually present in this phase of the disease (Anosa et al. 1992). The mild enlargement of the lymphoid nodules of the spleen in the $T$. brucei infections could indicate the declining role of humoral immunity in chronic trypanosomosis (Moulton 1986). These observations are milder in other groups (B-E) fed various spices, and this may be due to modulating effects of spices on the pathogenesis of ovine trypanosomiasis.

In this study, vascular congestion, disorganization of the hepatic cords, perivascular mononuclear cell infiltration, hepatocyte degeneration, hyperplasia of Kupffer cells, and erythrophagocytosis in the liver of infected animals. These are common histological lesions in ovine trypanosomosis, but milder in other groups fed various spices. The observed lesions in group A might be because the diet in group A had no herbs as compared with other diets (B-E), which are known antioxidants aiding in tissue repair and aiding in successful recovery from the lesions observed (Taylor and Authie 2004). There are differences in the extent of these reactions depending on the parasite species and species in the stages of infection.

In conclusion, herbs and combinations used in this study have significantly improved the lesions (both hematologic and pathologic) seen in experimental trypanosomosis caused by $T$. brucei infection in West African dwarf sheep. The best results were obtained from Diet E OG+VA combinations.

\section{REFERENCES}

Aguiyi JC, Obi CI, Gang SS, Igweh AC. 2000. Hypoglycaemic activity of Ocimum gratissimum in rats. Fitoterapia 71: 444-446.

Aliu YO. 2007. Veterinary Pharmacology. 1st eds. Tamaza publishing, Zaria.

Anosa VO, Logan-henfrey LL, Shaw MK. 1992. A light and electron microscopic study of changes in blood and bone marrow in acute haemorrhagic T. vivax infection in calves. Vet Pathol 29: 33-45.

Awah FM. 2010. Antioxidant activity, nitric oxide scavenging activity and phenolic contents of Ocimum gratissimum leaf extract. J Med Plant Res 4: 2479-2487.

Awoyomi OJ, Biobaku KT, Kehinde OO, Adebowale OO, Oyewusi JA. 2013. A survey of ethnoveterinary botanicals in Ogun State and their public health implication. Niger J Anim Prod 40: 198-208.

Biobaku KT, Abodunrin CO, Ajibola ES, Adenubi OT, Olukunle OJ, Thomas FC. 2009. Trypanocidal effect of aqueous extracts of Khaya senegalensis and Allium sativum with natural magnesium supplement in rat. Nig J Parasitol 30: 90-95.

Biobaku KT, Ajagbonna OP, Ajayi OL, Adebowale OO. 2008. Effect of magnesium chloride and diminazene aceturate in Trypanosoma bruce inoculated wistar albino rat. J Univ Agric Abeokuta B7: 64-70.

Dina OA, Saba AB, Adedapo AA, Akinyemi OA, Omobowale TO. 2002. Comparative efficacy study of Homidium bromide, diminazene aceturate and their combination on New Zealand White Rabbit, experimentally infected with Trypanosoma congolense. Trop Vet 20: 153-159.

Drury RAB, Wallington EA. 1967. Carleton's histological techniques. 4th eds. Oxford University Press, New York.
Felix JP, Mello D. 2005. Farm Animal Metabolism and Nutrition. CABI, United Kingdom.

Li SQ, Fung MC, Reid S, Inoue N, Lun ZR. 2007. Immunization with recombinant beta-tubulin from $T$. evansi induced protection against $T$. evansi, T. equiperdum and T. brucei infection in mice. Parasite Immunol 29:191-199.

Ho WY, Liang WS, Yeap SK, Beh BK, Yousr AHN, Alitheen NB. 2012. In vitro and in vivo antioxidant activity of Vernonia amygdalina water extract. Afr J Biotechnol 11: 4090-4094

Hoet S, Pieters L, Muccioli GG, Habib-Jiwan JL, Opperdoes FR, Quetin Leclercq J. 2007. Antitrypanosomal activity of triterpenoids and sterols from the leaves of Strychnos spinosa and related compounds. J Nat Prod 70: 1360-1363.

Igbokwe IO. 1994. Mechanisms of cellular injury in African trypanosomiasis. Vet Bull 64: 611-620.

Ikpeazu VO, Emmanuel O, Ekweogu CN, Akara EU, Ugbogu EA. 2019. A comparative nutritional assessment of leaf extracts of Ocimum gratissimum and Solanum aethiopicum. Am J Biomed Res 7: 27-31.

Itard J. 1989. African animal trypanosomiasis. Manual of Tropical Veterinary Parasitology. C.A.B International, Wallingford.

Jain NC. 1986. Schalm Veterinary Haematology. $4^{\text {th }}$ ed. Lea and Febiger, Philadelphia.

Joshua RA, Neilson JS, Oladosu LA. 1996. Heterophile antibodies to chicken erythrocytes in sheep infected with Trypanosoma congolense. Onderstepoort J Vet Res 63: 253-258.

Kaneko JJ, Howard CF Jr. 1989. Carbohydrate metabolism. In: Loeb WF, Quinby FW (eds) Clinical Chemistry of Laboratory Animals. Pergamon Press, New York.

Katunguka-Rwakishaya E, Murray M, Holmes PH. 1998. The influence of supplementation with cotton seed cake on the resistance of goats to primary and secondary challenges with Trypanosoma congolense and on their response to treatment. Vet Parasitol 70: 67-76.

Mackenzie PK, Boyt WP, Nesham VW, Pirie E. 1978. The aetiology and significance of the phagocytosis of erythrocytes and leucocytes in sheep infected with Trypanosoma congolense (Broden, 1904). Res Vet Sci 24: 4-7

Mahomoodally MF, Gurib-Fakim A, Subratty AH. 2005. Antimicrobial activities and phytochemical profiles of endemic medicinal plants of Mauritius. Pharm Biol 43: 237-242.

Mahomoodally MF, Gurib-Fakim A, Subratty AH. 2010. Screening for alternative antibiotics: an investigation into the antimicrobial activities of medicinal food plants of Mauritius. J Food Sci 75: M173M177.

Marcotty T, Simukoko H, Berkvens D, Vercruysse J, Praet N, Van den Bossche P. 2008. Evaluating the use of packed cell volume as an indicator of trypanosomal infections in cattle in eastern Zambia. Prev Vet Med 87: 288-300

Mbaya A, Kumshe H, Nwosu CO. 2012. The mechanisms of anaemia in trypanosomosis: a review. In: Silverberg D, (eds) Anaemia. INTECH Open Access Publisher, Croatia.

Morrison WI, Goddeeris BM, Teale AJ, Groocock CM, Kemp SJ, Stagg DA. 1987. Cytotoxic T-cells elicited in cattle challenged with Theileria parva (Muguga): evidence for restriction by class I MHC determinants and parasite strain specificity. Parasite Immunol 9: 563578.

Moulton JE. 1986. Structural and functional changes in the lymphoid organs of cattle infected with T. congolense. Trop Vet 4: 97-106.

Murray M, Morrison WI, Murray PK, Clifford DJ, Trail JCM. 1978. Trypanotolerance: a review. World Anim Rev 31: 2-12.

Murray M, Trail JCM, Turner DA, Wissocq Y. 1983. Livestock productivity and trypanotolerance. Network Train Manual, ILCA.

Oduye OO, Okunaiya OA. 1971. Haematological studies on the White Fulani and N'Dama breeds of cattle. Bull Epizoot Dis Afr 19: 213218.

Okaiyeto SO, Ajanusi OJ, Sackey AK, Tekdek LB. 2010. Changes in some haematological values associated with mixed Trypanosoma congolense and Haemonchus contortus infection in Yankassa sheep. Vet Res 3: 9-13.

Orhue NEJ, Nwanze EAC. 2009. Anti anaemic properties of Scoparia dulcis in Trypanosoma brucei infected rabbits. Afr J Biochem Res 3: 245-249.

Pugh DG. 2002. Sheep and Goat Medicine, $1^{\text {st }}$ eds. WB Saunders, Philadelphia.

Reitman S, Frankel S. 1975. A calorimetric method for the determination of serum glutamic oxaloacetic and glutamic pyruvic transaminase. Am J Clin Pathol 28: 56-63. 
Riou GE, Bernard J. 1980. Berenil induces the complete loss of kinetoplast DNA sequences. Biochem Biophys Res Commun 9: 350 354.

Taylor K, Authie ML. 2004. Pathogenesis of animal trypanosomiasis. In: Maudlin I, Holmes PH, Miles MA (eds) The trypanosomoses. CABI Publishing, Oxfordshire.
Van den Bossche PRGJ, Rowlands GJ. 2001. The relationship between the parasitological prevalence of trypanosomal infections in cattle and herd average packed cell volume. Acta Trop 78: 163-170.

Yakubu MT, Adebayo OJ, Egwim EC, Owoyele VB. 2005. Increased liver alkaline phosphate and aminotransferase activities following administration of ethanolic extract of Khaya senegalensis stem bark to rats. Biokemistri 17: 27-32 